\title{
Exocrine pancreatic secretion and plasma leptin and insulin levels in growing pigs of different genotypes*
}

\author{
R. Matyjek ${ }^{1}$, R. Zabielski ${ }^{2}$, Z. Długołęcka ${ }^{1}$ and T. Żebrowska ${ }^{1}$ \\ ${ }^{1}$ The Kielanowski Institute of Animal Physiology and Nutrition, Polish Academy of Sciences \\ 05-110 Jabtonna, Poland \\ ${ }^{2}$ Warsaw Agricultural University, Faculty of Veterinary Medicine, \\ Department of Physiological Sciences \\ Ciszewskiego 8, 02-786 Warsaw, Poland
}

\begin{abstract}
The objective of this study was to investigate PJ secretion in growing pigs of Polish synthetic line 990, Pietrain and Duroc breeds. The 990 and Pietrain pigs strongly responded with protein secretion to a meal, whereas the Duroc breed showed much weaker kinetics of postprandial pancreatic juice flow. No significant differences in plasma leptin were found, just a slight tendency towards a lower leptin ratio in synthetic line 990 . The observed trends may involve the inhibitory effect of plasma leptin on the exocrine pancreas resulting in a reduced ability to inhibit the exocrine pancreas. The presented data suggest that the insulo-acinar axis may play an important role in the regulation of exocrine pancreas secretion in pigs.
\end{abstract}

KEY WORDS: leptin, pancreatic secretion, pig, Pietrain, Duroc, synthetic line 990

\section{INTRODUCTION}

Exocrine pancreatic secretion in pigs depends on factors attributed mainly to nutrients (Żebrowska et al., 1987) and the circadian rhythm phase (Kiela et al., 1996). Previous studies describing characteristic Pietrain and Polish synthetic line 990 pig breeds showed significant differences in feed intake, daily gain and protein-energy deposition (Fandrejewski et al., 2001). Studies on pure pig breeds in regards to pancreatic exocrine function are lacking, therefore we aimed to examine the inbred differences in pancreatic secretion in terms of plasma leptin and insulin levels.

\footnotetext{
* Supported by the State Committee for Scientific Research, Grant No. 6PO6Z04021

${ }^{1}$ Corresponding author: e-mail: r.matyjek@ifzz.pan.pl
} 


\section{MATERIAL AND METHODS}

Six male pigs of each breed, initially of about $24 \mathrm{~kg}$ liveweight, were used. The pigs were surgically fitted with a chronic pancreatic duct catheter and a T-shaped duodenal cannula for collection and subsequent return of pancreatic juice (PJ) into the duodenum according to Pierzynowski et al. (1988). A commercial pelleted diet containing $17 \%$ crude protein and $12.6 \mathrm{MJ}$ EM was fed at a level of $3.5 \%$ body weight before the surgery and about $2.5 \%$ during the experimental period. The animals were fed twice a day at $8.00 \mathrm{a} . \mathrm{m}$. and 4.00 p.m.

Pancreatic juice was collected continuously from 7.30 a.m. to 4.00 p.m. for a total of $8.5 \mathrm{~h}$, in 30-min samples with juice returning into the duodenum. The samples of pancreatic juice were analysed for volume, total protein content by the Lowry method, trypsin activity by the modified method of Erlanger, and for amylase activity (Walker and Harmon, 1996). Blood samples were collected on EDTA and aprotinin, 30 min before feeding and 15, 30, 60, 120 and 240 min after the feed was offered. The samples were then centrifuged and plasma samples were kept frozen $\left(-80^{\circ} \mathrm{C}\right)$ for leptin (Multi-species Leptin RIA kit, Linco Research, USA) and insulin (Insulin RIA kit, DRG, USA) analyses.

\section{RESULTS}

After overnight fasting, $30 \mathrm{~min}$ before feeding, the mean volume of secreted PJ was the highest in Pietrain pigs $(1.1 \pm 0.4 \mathrm{ml} / \mathrm{kg} \mathrm{BW} / 30 \mathrm{~min})$. In Duroc and Polish synthetic line 990, the flow reached, respectively, $0.9 \pm 0.5$ and $0.8 \pm 0.3 \mathrm{ml} / \mathrm{kg}$ $\mathrm{BW} / 30 \mathrm{~min}$. Total protein output was the highest in the Pietrain and the lowest in Duroc lines (Figure 1). The highest trypsin and amylase activities were found in the synthetic Polish line 990, and the lowest, in Duroc pigs (data not shown). Feeding significantly increased the PJ volume and total protein output in synthetic line 990 and Pietrain pigs. After about 1 h, PJ secretion decreased. In Pietrain and Duroc pigs, the data obtained after $1 \mathrm{~h}$ of the postprandial phase were below the initial interdigestive secretion values (Figure 1).

Protein output during the first $4 \mathrm{~h}$ of the digestive period was the highest in synthetic line 990 , and smaller by about 20 and $40 \%$ in Pietrain and Duroc pigs, respectively (ANOVA, $\mathrm{P}=0.0007$ ). Trypsin output in Pietrain and 990 lines was similar and larger by $60 \%$ as compared with Duroc pigs. Similar trends, not statistically significant, were observed for amylase activity (not shown). 


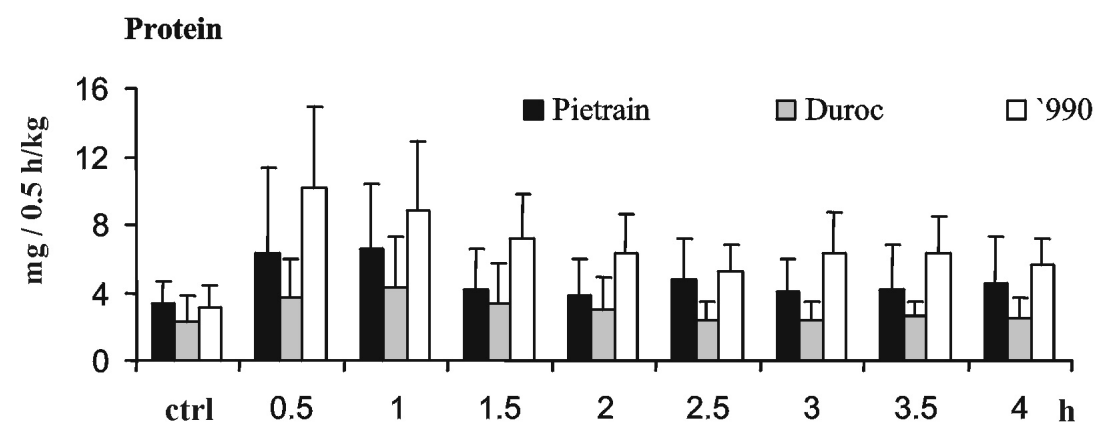

Figure 1. Pancreatic protein output during $4 \mathrm{~h}$ of collection. Control sample (ctrl) reflects $30 \mathrm{~min}$ of preprandial secretion and the following samples $(0.5-4)$ reflect the postprandial secretion

Plasma leptin did not change statistically throughout the groups and periods, however, a stable pattern was observed in Pietrain pigs, remaining at a level of 3.5 $\mathrm{ng} / \mathrm{ml}$ for $4 \mathrm{~h}$, whereas in other breeds it returned to initial preprandial values just after $1 \mathrm{~h}$. The concentration of plasma insulin before feeding was similar (Table 1), and rose approximately twofold after feeding in Pietrain and line 990, but not in Duroc pigs.

Table 1. Plasma insulin and leptin concentrations in pigs of different breeds. Blood was withdrawn in the interdigestive ( $0 \mathrm{~min}$ ) and postprandial periods (15-240 $\mathrm{min})$

\begin{tabular}{llcccccc}
\hline \multirow{2}{*}{ Homone } & \multirow{2}{*}{ Breed } & \multicolumn{6}{c}{ Sampling - time after feeding, min } \\
\cline { 3 - 8 } & & 0 & 15 & 30 & 60 & 120 & 240 \\
\hline \multirow{2}{*}{ Leptin, } & Pietrain & 3.3 & 3.4 & 3.5 & 3.3 & 3.5 & 3.5 \\
$\mathrm{ng} / \mathrm{ml}$ & Duroc & 3.4 & 3.5 & 3.0 & 3.0 & 3.2 & 3.2 \\
& Line 990 & 3.1 & 3.4 & 2.9 & 3.0 & 3.1 & 3.2 \\
& & & & & & & \\
Insulin, & Pietrain & 4.5 & 8.9 & 10.5 & 21.4 & 14.0 & 11.2 \\
U/ml & Duroc & 3.8 & 4.0 & 6.2 & 16.9 & 14.9 & 8.3 \\
& Line 990 & 4.7 & 10.6 & 29.7 & 30.8 & 21.3 & 14.1 \\
\hline
\end{tabular}

\section{DISCUSSION}

In the interdigestive period the volume, protein and enzyme outputs in PJ of each breed did not statistically differ due to high data scatter, a natural consequence of the periodic nature of pancreatic secretion in pigs (Kiela et al., 1996). After integrating the data into a cumulative flow, protein and enzyme outputs, several differences were found providing two general secretory profiles: line 990 and Pietrain pigs strongly responding to a meal with pancreatic protein (enzyme) secretion (ANOVA for $8 \mathrm{~h}, \mathrm{P}=0.0014$ ), and Duroc pigs, with a weaker response 
to a feed (ANOVA for $8 \mathrm{~h}, \mathrm{P}=0.0135$ ). Interestingly, plasma insulin followed the general pattern of pancreatic juice secretion. Namely, the prandial plasma insulin and pancreatic protein (enzyme) output were enhanced in Pietrain and line 990 pigs, whereas not in Duroc pigs. It seems that in Pietrain and line 990 pigs, the exocrine secretion of the pancreas can be promptly stimulated by the insuloacinar axis, whereas in Duroc pigs this mechanism is delayed and less effective. The reason for the differences may include a number of factors, like vagal nerve activity and/or endocrine influences involving GIP and other regulatory peptides. Further studies are needed. The absence of differences in plasma leptin confirm the results obtained by Berg et al. (2003), and may result from the similar fat content in the carcass.

\section{CONCLUSIONS}

These results show that the secretion of pancreatic juice in growing pigs of different genotypes corresponds to plasma insulin but not to plasma leptin.

\section{REFERENCES}

Fandrejewski H., Raj S., Waremko D., Buraczewska L., Skiba G., 2001. Protein and energy metabolism in pigs of two genotypes. In: A. Chwalibog, K. Jakobsen (Editors). Energy Metabolism of Farm Animals. EAAP Publication No. 103. Wageningen Pers, Wageningen, pp. 373-375

Kiela P., Zabielski R., Podgurniak P., Midura M., Barej W., Gregory P., Pierzynowski S.G., 1996. Cholecystokinin- 8 and vasoactive intestinal polypeptide stimulate exocrine pancreatic secretion via duodenally mediated mechanisms in the conscious pig. Exp. Physiol. 81, 375-4

Pierzynowski S.G., Weström B.R., Karlsson B.W., Svendsen J., Nilsson B., 1988. Pancreatic cannulation of young pigs for long-term study of exocrine pancreatic function. Can. J. Anim. Sci. 68, 953-959

Walker J.A., Harmon D.L., 1996. Technical note: A simple, rapid assay for a-amylase in bovine pancreatic juice. J. Anim. Sci. 74, 658-666

Żebrowska T., Low A.G., 1987. The influence of diets based on whole wheat, wheat flour and wheat bran on exocrine pancreatic secretion in pigs. J. Nutr. 117, 1212-1216

\section{STRESZCZENIE}

Wydzielanie soku trzustkowego i stężenia leptyny i insuliny u rosnących prosiąt różnych genotypów

Celem badań było porównanie wydzielania trzustkowego i stężenia leptyny i insuliny w osoczu krwi u rosnących świń rasy Pietrain, Duroc i syntetycznej linii 990. Egzokrynna odpowiedź trzustki na podawanie pokarmu u rasy Pietrain i linii 990 była silniejsza niż u rasy Duroc, u której jednocześnie poziom insulinemii poposiłkowej był niższy w porównaniu z pozostałymi rasami. Stężenie leptyny w osoczu nie różniło się między badanymi rasami.

W podsumowaniu stwierdzono, że mechanizm kontroli wydzielania soku trzustkowego związany jest z rasą świń. 